\title{
Reducing Job Insecurity and Increasing Performance Ratings: Does Impression Management Matter?
}

\begin{abstract}
Prior research on job insecurity has demonstrated its detrimental effects on both employees and the organization, yet no research has detailed how people actively deal with it. Drawing from proactivity research, this article argues that job insecurity prompts a proactive use of impression management tactics in the workplace. The effectiveness of these tactics depends on the level of supervisory liking for the employee and the attributions supervisors make regarding the employee's motives for the impression management behaviors (i.e., for the good of the organization or for self-interest). A three-wave survey study of 271 Chinese employees and their supervisors showed that employees experiencing job insecurity in Time 1 reported using a variety of tactics to impress their supervisors at Time 2 and that these tactics curbed the affect associated with job insecurity and enhanced supervisor rated performance, through supervisor's liking and attributed motives. The relationship between impression management and increased supervisor-rated performance was moderated by supervisor attributions; the relationship between impression management and reduced affective job insecurity depended on supervisor liking.

Keywords: Job Insecurity, Proactivity, Impression Management, Supervisor Liking, Supervisorattributed Motive
\end{abstract}

\section{Reducing Job Insecurity and Increasing Performance Ratings: Does Impression} Management Matter? 
As organizations deal with a global economic recession, shifts from manufacturing to service economies, and the rise of global competition, workers worldwide are experiencing job insecurity. One recent journalist claims that more than half the world's workforce lacks job security and that the number is growing (Schifferes, 2009). In a longitudinal study of two nationally representative samples of the U.S. population, Burgard, Brand, and House (2009) found that persistent job insecurity was a stronger predictor of poor self-rated health and depressive symptoms than was either smoking or hypertension. In fact, chronic job insecurity related more strongly to health declines than did actual job loss or unemployment. In addition to its impact on physical and psychological well-being, job insecurity has attitudinal and behavioral consequences that are detrimental to both individuals and the organizations that employ them. These include absenteeism, turnover, lower job satisfaction, and poor performance (Ashford, Lee, \& Bobko, 1989; Cheng \& Chan, 2008; Sverke, Hellgren, \& Näswall, 2002).

As Burgard et al. (2009) suggested, there is an imminent need to explore ways to counteract job insecurity, to benefit both individuals and organizations. While much research attention has focused on contextual influences that might ameliorate job insecurity (e.g., Brockner, Grover, Reed, \& DeWitt, 1992; Brockner, Spreitzer, Mishra, Hochwarter, Pepper, \& Weinberg, 2004; Lee, Bobko, \& Chen, 2006), employees also need to attend to their own health and well-being, even in the absence of organizational initiatives. However, existing research on how individual employees actively respond to job insecurity is limited. For example, whereas Roskies, Louis-Guerin, and Fournier (1993) showed that people with positive personality attributes, such as positive affectivity, tended to use cognitive redefinition rather than avoidance to deal with job insecurity, their cross-sectional data could not reveal causal relationships between job insecurity and these coping strategies. The purpose of our study is to examine 
people's behavioral responses to job insecurity and determine how those responses affect their experience of job insecurity and their supervisor's view of their performance.

Drawing on proactivity and social influence theory, we propose that job insecurity creates a motive to engage in social influence attempts using impression management tactics. Often characterized as behaviors that people employ to protect their self-images and influence the way they are perceived by authorities or significant others (Schlenker, 1980), impression management tactics stimulated by feelings of job insecurity will likely have two effects. First, they may reduce employees' feelings of job insecurity as the employees observe themselves being agentic —-someone who is working in the situation to create positive outcomes. Second, impression management tactics may increase the actual security of the job by giving the supervisor a more positive impression of the employee. We further propose that these main effects will be qualified by both whether the supervisor makes positive attributions for the motives underlying the subordinate's proactive behaviors and how much the supervisor likes the subordinate.

\section{Theoretical Background and Hypotheses}

\section{Job Insecurity and Impression Management}

A review of job insecurity literature suggests that the experience of job insecurity is a common organizational phenomenon that can occur independent of any particular crisis context (Lee et al., 2006; Rosenblatt \& Ruvio, 1996). As job insecurity is associated with much uncertainty, it is a situation ripe for the emergence of proactive behaviors (Grant \& Ashford, 2008; Griffin, Neal, \& Parker, 2007). Defined as self-initiated, anticipatory action that aims to change and improve the situation or oneself (Grant \& Ashford, 2008; Parker, Williams \& Turner, 2006), proactive behaviors reflect the fact that "[e]mployees do not just let life happen to them. Rather, they try to affect, shape, curtail, expand, and temper what happens in their lives” (Grant 
\& Ashford, 2008: 1). Uncertain situations provide two motives for proactivity. The first is uncertainty reduction (Grant \& Ashford, 2008). When employees encounter ambiguity, they are generally motivated to reduce it (e.g., Festinger, 1957; Hogg, 2000, 2007). Proactive behaviors such as information and feedback seeking and relationship building (Ashford, 1986; Chan \& Schmitt, 2000; Morrison, 1994) reduce uncertainty, because the actors gain information and support that enables them to predict, understand, and influence their environments in advance. Uncertainty also represents an opportunity. In objectively uncertain situations, things are unclear (e.g., “who might be laid off?”), and employees may see a chance to shape how the situation unfolds. Just as they use the uncertainty surrounding work-role transitions as an opportunity to craft their roles to better suit them (Black \& Ashford, 1995; Nicholson, 1984), employees experiencing the uncertainties associated with job insecurity may also be motivated to try to affect outcomes. One way to do so is by engaging in impression management.

Impression management, defined as the process by which people attempt to influence the image others have of them (Rosenfeld, Giacalone, \& Riordan, 1995), is a prominent social influence strategy in organizational contexts. According to Barry and Watson (1996), people in lower status positions (subordinates) use social influence tactics strategically to influence higherstatus others (supervisors) through verbal and/or symbolic actions. They expect that these actions will bring about desirable changes in the cognitions or behaviors of the target (e.g., supervisors) that would not have occurred otherwise. Social influence attempts relate significantly to employee selection outcomes (e.g., Baron, 1989; Gilmore \& Ferris, 1989), supervisor performance ratings (e.g., Kipnis \& Schmidt, 1988; Wayne \& Ferris, 1990; Wayne \& Kacmar, 1991), pay increases (e.g., Bartol \& Martin, 1988, 1990), and promotions (e.g., Hui, Lam, \& Law, 2000). Therefore, subordinates experiencing the uncertainties associated with job insecurity 
may be especially motivated to engage in impression management with their supervisors. Such behaviors may give employees hope that they might decrease the likelihood of any negative job action, and they also actually could affect the real probability of job loss if supervisors are affected by them. In addition, by engaging in proactive action, employees should feel more efficacious, which also may reduce their feelings of job insecurity.

If impression management is motivated by the goal relevance of created impressions, the value of desired outcomes, and the discrepancy between current and desired images (Leary \& Kowalski, 1990), then job insecurity is a likely trigger for it. Maintaining a job is an important goal for most people, and, when feeling insecure about their jobs, creating a positive workplace image becomes highly goal-relevant. Employees want important others to see that they are valuable to the organization and may believe they have little power to change the situation. In organizations, people with more administrative power usually control access to resources for those in less powerful positions (Simon, 1997). Therefore, engaging in impression management tactics is a way to gain instrumental and social support from superiors and potentially influence their decisions. Our prediction is consistent with frequent popular-press suggestions that engaging impression management is a way to keep one’s job in tough economic times (e.g., Loza, 2009; Turner, 2013; Vale, 2012). Therefore, we propose:

Hypothesis 1: Job insecurity relates positively to employees' use of impression management tactics.

\section{Effects of Impression Management on Job Insecurity and Supervisor-Rated Performance}

Our discussion suggests that employees’ impression management tactics can influence job insecurity in two ways, namely, by reducing the employee's feelings of job insecurity (perhaps by engendering hope for a better job future) and by influencing their actual job security 
through influencing the supervisor to see their performance more positively. We propose that the degree to which impression management might have such effects depends on the attributions the target of those impression management attempts (the supervisor, in this case) makes about the motives underlying the subordinate's behaviors and how much he or she likes the subordinate. Prior research has suggested that supervisors can attribute a seemingly similar set of behaviors by different employees to dissimilar motives, such as altruistic or instrumental (Allen \& Rush, 1998; Eastman, 1994). When supervisors make the former attribution, they assume that the behavior is motivated by a desire to improve and contribute to the organization. When they make the latter attribution, the perception is that the behavior is motivated by a desire to look good, obtain organizational rewards, or build up favors for later exchange (Allen \& Rush, 1998; Grant \& Mayer, 2009; Lam, Huang \& Snape, 2007). Behaviors attributed to altruistic motives are likely to influence performance judgments positively, whereas those associated with instrumental motives may be devalued or discounted (e.g., Hui et al., 2000; Lam et al., 2007).

Because proactive activities are discretionary, they are thought to be especially indicative of who a person is and, thus, observers often actively consider the motives underlying such behavior (Grant \& Ashford, 2008). These attributions, in turn, can influence the effectiveness of the proactive behavior. This suggestion is in line with recent findings in which the attributions supervisors made for feedback seeking (Lam, et al., 2007) and organizational citizenship (Grant \& Mayer, 2009) behaviors by their subordinates affected their responses to those behaviors. Based on these findings and this argument, we propose that the employee's job insecurity induced impression-management tactics are more effective to the extent that the supervisor makes altruistic attributions for them. 
In addition to cognitive attributions of the motives, the general affective regard that supervisors have toward subordinates also should impact impression-management effectiveness. Research on affect and cognition has shown that positive affect cues positive memories (Isen, Johnson, Mertz, \& Robinson, 1985; Isen, Niedenthal, \& Cantor, 1992) such that when a supervisor likes the employee, he or she tends to recall positive rather than negative instances of the employee's behaviors, which may lead to a better evaluation of the employee's performance and more support provided to the employee (Cardy \& Dobbins, 1986; Judge \& Ferris, 1993; Wayne \& Ferris, 1990; Wayne \& Liden, 1995).

Supervisory liking and attributed motive also could influence the effectiveness of impression management for reducing employees' subsequent job insecurity feelings. As discussed, under these conditions, the supervisor tends to provide more support to that subordinate, including material, informational, and emotional support. With more resources, more information regarding the job and the organization, and/or more emotional caring, the employee may grow less anxious and more hopeful, and their feelings of job insecurity should reduce accordingly. Employees who are less well-liked or those whom the supervisor suspects of having instrumental motives receive less reinforcement and may be less confident of the effectiveness of their impression management. Therefore, we propose:

Hypothesis 2: Supervisor-attributed motive moderates the effectiveness of impression management tactics on changes in job insecurity and performance rating changes. Specifically, impression management tactics produce more negative changes in job insecurity and more positive changes in performance ratings when supervisors make altruistic motive attributions for the subordinates' impression management behaviors. 
Hypothesis 3: Supervisor liking moderates the effectiveness of impression management tactics on changes in job insecurity and performance ratings. Specifically, impression management tactics produce more negative changes in job insecurity and more positive changes in performance ratings when supervisor liking is high.

\section{Method}

We collected three rounds of data (from June 2007 to December 2008) from a construction company and a manufacturing firm in China, both of which are large state-owned enterprises. We asked the participants to complete questionnaires during work hours, on company premises. Their participation was voluntary and participants were told that the survey was for a research project and their responses would be kept confidential by the research team. Both the employee and supervisor survey were anonymous. To match the employee and supervisor questionnaires and the data across waves, all questionnaires were coded. Each participant received $15 \mathrm{RMB}$ ( USD2.2) for returning the first-round questionnaire and additional 20 RMB ( USD3.0) for returning both the second and third rounds. During the first wave of data collection, we distributed 768 questionnaires to focal employees and 143 to supervisors. We received 692 valid employee questionnaires and 129 valid supervisor questionnaires (for response rates of $90.1 \%$ and $90.2 \%$, respectively), which gave us a data pool of 476 subordinate-supervisor matched pairs. Six months later (Time 2), we collected data in the two firms using the same procedure. We targeted the subordinate-supervisor dyads that completed the first wave and received 414 responses (for a dyadic response rate of $87.0 \%$ ). One year later (Time 3), we collected 271 valid questionnaires from the wave 2 respondents as our final sample (for a dyadic response rate of 65.5\%) including 130 from the manufacturing firm and 141 from the construction firm. In the final sample, $72.7 \%$ of the subordinate participants 
were males, 54.1\% reported ages between 20 and 40 years, $74.3 \%$ had finished at least high school, and $79.2 \%$ had at least two years of organizational tenure. We followed Lance, Vandenberg and Self (2000) and conducted a subject attrition analysis. The results showed no detectable differences created by attrition ${ }^{1}$.

\section{Measures}

At Time 1, subordinate questionnaire measured employees' job insecurity and their demographic and other control variables. Supervisors reported their liking of subordinates. At Time 2, impression management tactics were measured via employee self-reports and supervisors rated their employees' job performance. At Time 3, employees' job insecurity levels were measured again. Supervisors rated subordinates' job performance and altruistic motives for impression-management behaviors. To ensure the equivalence of the Chinese and English versions, we used the translation-back translation procedure (Brislin, 1980) and Chinese language experts examined the questionnaire to ensure that the items were easily interpretable. Unless otherwise noted, all the following scales used five-point Likert measures ranging from strongly disagree (1) to strongly agree (5). Job insecurity was measured with a 10-item measure of affective job insecurity (Huang, Lee, Ashford, Chen, \& Ren, 2010; Huang, Niu, Ashford, \& Lee, 2012a). A sample item is “I am scared by the thought of losing my job.” The Cronbach’s alpha reliability estimates were .82 and .88 at $\mathrm{T} 1$ and T3, respectively. We used four items from Wayne and Ferris (1990) to measure the supervisor's liking of the subordinate. The four items were rated on five-point Likert scales, with anchors of I don't like this subordinate at all (1) to I like this subordinate very much (5) for the first item and strongly disagree (1) to strongly agree (5) for the other items. The coefficient alpha was .89. A 23-item scale developed by Wayne and

\footnotetext{
${ }^{1}$ The results of subject attrition analysis are available on request.
} 
Ferris (1990) was used to measure subordinate impression management tactics, including selffocused, job-focused, and supervisor-focused tactics. Subordinates reported how often they had engaged in a particular behavior at work and their interaction with the supervisor on a five-point scale ranging from never (1) to always (5). Sample items were, "Work hard when you know the results will be seen by your supervisor” (self-focused), "Make your supervisor aware of your accomplishments” (job-focused), and “Take an interest in your supervisor’s personal life” (supervisor-focused). The coefficient alpha was .94. Job performance was measured by four items developed by Podsakoff and Mackenzie (1989). Supervisors rated their agreements with statements about subordinates' in-role performance, such as "This employee always completes the duties specified in his/her job description.” The coefficient alphas at T2 and T3 were .77 and .72, respectively. Altruistic motive for impression management behaviors was measured with the 6-item altruistic motivation scale developed by Allen and Rush (1998). Supervisors were asked to describe to what extent they attributed the reasons for the subordinate's proactive behaviors to such motives as "sense of moral standard" and "commitment to the organization." The coefficient alpha was .76. To control for contextual influences on employees' job insecurity change, we measured employees' perception of the likelihood of potential changes over the next few years within their organization using a 12-item scale developed by Ashford et al. (1989) at Time 1. A sample item is "the organization will undertake a major restructuring." The coefficient alpha was .73. Furthermore, trait insecurity may be a potential confounding variable that influences the job insecurity-impression management relationship. To control for it, we included a measure of neuroticism, because insecurity is a typical characteristic of people high in neuroticism (McCrae \& Costa, 1987). We used five items (e.g., security, stability) from Goldberg's (1992) measure of the big five personality dimensions. The coefficient alpha was .78. 


\section{Results}

To analyze our data, we first conducted a measurement invariance test to ensure that the different measurement occasions yielded equivalent representations of job insecurity and job performance, both of which were measured twice (Chan, 1998; Vandenberg, 2002; Vandenberg \& Lance, 2000). Support for measurement invariance would suggest that the change between two measurement occasions is quantitative (i.e., changes in scores) rather than qualitative (i.e., changes in people's understanding of the construct). The results supported the measurement invariance of the two measures. ${ }^{2}$ Because one supervisor rated multiple employees (average cluster size equals to 1.40), we also checked the design effects to examine whether analyzing the data in the individual level would create any bias. Using the formula in Kline (2010), we found that the design effects in our study context were not sufficient to result in appreciable bias if assuming score independence. We therefore proceeded with our analyses.

To examine the factor structure of our study variables, we estimated a measurement model that included all the latent variables used in our model (i.e., job insecurity, impression management, supervisor liking, altruistic motive, performance rating, trait insecurity and organizational change perception) in Mplus 6.0 (Muthén \& Muthén, 2009). Given the number of variables, we created three parcels of items for all of the variables with more than three items to simplify the model (Little, Cunningham, Shahar, \& Widaman, 2002). The exception was impression management, we used domain representative approach suggested by Kishton and Widaman (1994) because it is a multidimensional construct. The results of the confirmatory factor analysis showed that all factor loadings were statistically significant, with good overall measurement model fit $\left(\chi^{2}[369]=509.66 ; \chi^{2} / d f=1.48 ; \mathrm{CFI}=.96 ; \mathrm{TLI}=.95 ; \mathrm{RMSEA}=.04\right.$

\footnotetext{
${ }^{2}$ The results of measurement invariance tests are available on request.
} 
$[.03, .05]$; SRMR $=.05)$. The descriptive statistics and correlations among the variables were presented in Table 1.

[Insert Table 1 about here.]

Before estimating the structural model, we performed a latent mean structure analysis in Mplus 6.0 (Muthén \& Muthén, 2009) and found that the results confirmed the negative change of job insecurity $(\Delta M=-.21 ; s . d .=.21 ; p<.05)$ and the positive change of performance $(\Delta M=.24$; s.d. $=.23 p<.05)$ over time. We then used the latent change score modeling (LCSM) procedures developed by McArdle and colleagues (e.g., McArdle, 2009; McArdle \& Nesselroad, 1994) to estimate the structural model. LCSM creates a latent change score by adding a set of unity constraints on the observed scores of the same variable on two measurement occasions, thereby capturing the true difference over two time points (McArdle \& Nesselroad, 1994). Furthermore, to estimate the moderation effect of latent variables, we incorporated the estimation of the latent change score into the framework of latent moderated structural equation modeling (LMS) (Klein \& Moosbrugger, 2000). The overall model was presented in Figure 1.

[Insert Figure 1 about here.]

The relationship between job insecurity and impression management was positive $(\gamma=.19$, $p<.01)$. Therefore, Hypothesis 1 was supported. The results of the LMS in Table 2 showed that the main effect of impression management was insignificant for the job insecurity change $(\beta$ $=.18, n . s$. $)$ and performance rating change $(\beta=-.10, n . s$.$) . These main effect results need to be$ interpreted in light of the hypothesized interactions. The interaction between impression management and supervisor attributed motives exerted a marginally significant effect on performance rating change $(\omega=.26, p<.10)$ but not on job insecurity change $(\omega=-.10$, n.s. $)$. The interaction between impression management and supervisor liking exerted a significant 
effect on job insecurity change $(\omega=.30, p<.05)$ but not on performance rating change $(\omega=.04$, n.s.). Thus, Hypotheses 2 and 3 both received partial support. Regarding overall model fit, because LMS does not generate a fit index, we conducted a log-likelihood difference test $(\Delta-2 L L)$. The results confirmed the improvement of fit of the moderated structural equation model compared with the corresponding linear model $(\Delta-2 L L[38]=1698.35, p<.01)$.

[Insert Table 2 about here.]

We plotted the significant interaction effects to facilitate the interpretation of the findings. In Figure 2 we depicted the effect of the interaction between impression management and supervisor-attributed motive on performance rating change. The relationship between impression management and performance rating increase was significant in the low ( -1 standard deviation) attributed motive condition $(\beta=-.36, p<.05)$ but not in the high $(+1$ standard deviation) condition $(\beta=.16, n . s$.$) . More specifically, people in high condition generally tend to enjoy a$ greater increase of performance rating than people in low condition. Figure 3 showed the effect of the interaction between impression management and supervisor liking on job insecurity decrease. A closer investigation of the coefficients for the high and low conditions suggested that the relationship between impression management and job insecurity decrease in the high supervisor liking condition was significant $(\beta=.48, p<.01)$, but was not significant in the low liking condition ( $\beta=-.11$, n.s.). The error covariance between the two outcome variables, i.e., job insecurity change and performance rating change, was insignificant ( $\psi=-.03$, n.s.). The scale we used for impression management has three dimensions, job-focused, supervisor-focused and selffocused. The results at dimensional level are similar yet slightly different from each other. We report and discuss the results in Appendix.

[Insert Figure 2 and Figure 3 about here.] 


\section{Discussion}

Our study investigated employees’ behavioral responses to job insecurity using a threewave, time-lagged design. When experiencing job insecurity, our sample of Chinese employees responded proactively by engaging in impression management. The effects were twofold. First, impression management tactics helped reduce employees’ affective job insecurity, as long as their supervisors liked them. Second, the tactics influenced employees’ supervisor-rated performance, depending on whether supervisors made high altruistic attributions of their motives.

This study has several strengths and contributions to the literature. First, we move beyond the stress-strain and social exchange frameworks typically invoked in this literature (e.g., De Cuyper \& De Witte, 2006; Hellgren \& Sverke, 2003; Kraimer, Wayne, Liden, \& Sparrowe, 2005; Wong, Wong, Ngo, \& Lui, 2005) to examine how employees proactively respond to job insecurity through impression management. The shift recognizes that when experiencing job insecurity, employees are probably not just hoping to reduce stress and feel better, but also to shape their situation and outcomes proactively. So for example, when a layoff makes the environment highly unstable and ambiguous for survivors (Brockner et al., 1992, 2004), we are likely to observe high levels of proactive use of impression management tactics.

This study also contributes to our understanding of the dynamics of job insecurity experience over time. While research has typically focused on job insecurity’s influence on health, attitudinal, and performance outcomes, we showed how behavioral responses to job insecurity in the form of impression management tactics influenced subsequent feelings of job insecurity. Empirically, the lack of longitudinal data in job insecurity research has limited the study of possible strategies that employees can use when they face job insecurity (Sverke et al., 
2002). Our three-wave design shows for the first time that employees can take steps to change their job insecurity over time through impression management tactics. Our design further strengthens the interpretation of our findings by minimizing the threat of common method bias and supporting an inference of possible over-time causal relationships. Moreover, our findings also provide further evidence about the construct validity of the recently developed affective job insecurity scale (Huang et al., 2010, 2012a). Future research could examine the discriminant validity of affective job insecurity using other measures, such as Probst's (2003) satisfaction with job insecurity scale or job security as a component of job satisfaction (e.g., Selzer, 1950).

Finally, this study contributes to the impression management literature. Most impressionmanagement research focuses on selection and performance appraisal contexts (e.g., Delery \& Kacmar, 1998; Elllis, West, Ryan, \& DeShon, 2002); the findings from our study demonstrate that other situations, such as those inducing job insecurity, also activate impression management attempts. Our findings suggest that the effectiveness of those attempts will depend in part on the supervisor's attitudes. As suggested by Figure 2, employees whose supervisors attributed their behavior to an altruistic motive tended to receive higher performance rating increase than those whose supervisors made less of this attribution. Such difference is bigger if employees engage in a high level of impression management behaviors. Figure 3 suggests that doing impression management will not help employees feel less insecurity if they are not liked by their supervisors. However, when supervisor liking is high, impression management will bring a substantial amount of job insecurity decrease. Overall, our results imply that the impact of employees’ proactive attempts to shape their situation in response to job insecurity critically depends on the quality of their relationship with their supervisor as well as the extent that their proactive behaviors are viewed as attempts to make contributions to the organization. These findings 
suggest practical advice to employees: they should attend to and work to improve supervisors' affect toward them and work to display an interest in the organizations and others in their impression management efforts.

This study has several limitations and suggests important areas for future research. First, in addition to impression management, it could also be interesting to study other types of proactive behavioral responses to job insecurity such as feedback seeking, network building, or other strategies people undertake to save their jobs. These might serve as a useful complement to the problem versus emotion-focused coping framework suggested by Lazarus and Folkman (1984).

Second, the moderating hypotheses received partial support and needs future research attention. In Hypothesis 2, we hypothesized a moderating effect of attributed motives on both performance rating change and job insecurity change, but results only supported the former. This pattern may reflect that attributed motive is a cognition that the supervisor makes. As such, its effect on performance is straightforward: the employee is seen as caring about the group or organization and so is better appreciated and higher rated. The connection to the employee's experience of job insecurity is less clear. Employees may not be aware of the supervisor's attribution for their proactive efforts and therefore won't necessarily experience any reduction in insecurity as a result. In this way, impression management "works" for employees perceived as having altruistic motives as it affects their supervisor's view of them, but it does not necessarily make them feel better.

In Hypothesis 3, we hypothesized moderating effect of supervisor liking on both performance rating change and job insecurity change, but results only supported the latter. This implies a personal benefit of impression management tactics accruing to individuals who are 
well liked by the supervisor (i.e., feeling less job insecurity) is likely illusory as those same behaviors had no influence on the supervisors' rating of the individuals' performance. Regarding overtime effects, although we found the well-established positive impact of liking on supervisor performance rating at both times (Lefkowitz, 2000), we did not find a moderating effect of liking on performance rating change. This may be so because the effect of liking was reflected in the Time 2 performance rating and perhaps did not change over the time period of the study. Future research might examine these effects using different design, other contexts, and additional moderators. For example, when experiencing job insecurity, high self-monitors, who are more sensitive to social cues and adapt their behaviors to fit social situations (Snyder, 1974), may be more effective impression managers, and employees working remotely may be more motivated to convey their efforts and accomplishments to their supervisors, who lack opportunities to observe their performance (Barness, Diekmann, \& Seidel, 2005).

Relatedly, although the results in Table 1 supported the well-established negative relationship between job insecurity and performance rating, the common variance between job insecurity change and performance rating change after controlling for all other effects in the model is insignificant. It may be that it takes time for any performance-rating increase to be internalized such that it influences the affective job insecurity measure that we used. Future research should conduct a longitudinal examination of the relationship between them.

Finally, our research setting may have impact on our findings. Whereas the Chinese government's protection and support buffered SOEs from the brunt of the global economic recession occurring during the period of our data collection, many Chinese SOEs during this period adopted performance management programs in which employees could be fired or lose desired job features if they did not perform satisfactorily. These programs, combined with the 
large labor supply in China, made job insecurity an increasing concern to SOE employees in China at the time of our study. However, Chinese employees may view and respond to job insecurity differently than would Western employees. Historically, Chinese employees have had higher job security expectations than employees in the West due to a predominant "iron rice bowl" (life time employment) philosophy (Huang, Zhao, \& Lee, 2012b) and therefore may respond more negatively to job insecurity. In addition, social influence tactics may differ across cultures. For example, Xin and Tsui (1996) found that Asian managers use significantly more ingratiation and exchange tactics than Caucasians. Research should extend our findings by looking at job insecurity and its impact on impression management cross-culturally.

\section{Conclusion}

When employees feel insecure about their jobs, they can use a variety of impression management tactics to influence their situations, instead of just being "victims." Our results suggest that employees should update their supervisors about what they are doing and how well they are doing it, as well as find ways to increase the interpersonal affective regard with supervisors and the altruistic attributions they might make for their behavior. These agentic tactics available to individuals supplement organizations' efforts to reduce job insecurity by providing employees with information describing the organization's resources and supports available to help employees deal with feelings of insecurity. 


\section{References}

Allen, T.D., \& Rush, M.C. (1998). The effects of organizational citizenship behavior on performance judgments: A field study and a laboratory experiment. Journal of Applied Psychology, 83, 247-260. doi:10.1037//0021-9010.83.2.247

Ashford, S. J. (1986). Feedback-seeking in individual adaptation: A resource perspective. Academy of Management Journal, 29, 465-487. doi: 10.2307/256219

Ashford, S. J., \& Black, J. S. (1996). Proactivity during organizational entry: Antecedents, tactics, and outcomes. Journal of Applied Psychology, 81, 199-214. doi: $\underline{10.1037 / 0021-}$ $\underline{9010.81 .2 .199}$

Ashford, S. J., Lee, C., \& Bobko, P. (1989). Content, causes, and consequences of job insecurity: A theory-based measure and substantive test. Academy of Management Journal, 32, 803829. doi: $10.2307 / 256569$

Barker, R. G. (1968). Ecological psychology: Concepts and methods for studying the environment of human behavior. Stanford, CA: Stanford University Press.

Baron, RA.(1989). Impression management by applicants during employment interviews: The "too much of a good thing effect". In R.W. Eder \&G.R Ferris (Eds.), The employment interview: Theory, research, and practice (pp. 204-215). Newbury Park, CA: Sage Publications.

Barness, Z.I. Diekmann, K.A., \& Seidel, M.L. (2005). Motivation and opportunity: The role of remote work, demographic dissimilarity, and social network centrality in impression management. Academy of Management Journal, 48, 401-419.

doi:10.5465/AMJ.2005.17407906 
Barry, B., \& Watson, M. R. (1996). Communication aspects of dyadic social influence: A review and integration of conceptual and empirical developments. In B. R. Burleson (Ed.) Communication Yearbook (Vol. 19, pp. 269-317). Newbury Park, CA: Sage.

Bartol, K.M., \& Martin, D.C. (1988). Influences on managerial pay allocations: A dependency perspective. Personnel Psychology, 41, 361-378. doi:10.1111/j.1744-6570.1988.tb02390.x

Bartol, K.M., \& Martin, D.C. (1990). When politics pays: Factors influencing managerial compensation decisions. Personnel Psychology, 43, 599-614. doi:10.1111/j.1744$\underline{6570.1990 . t b 02398 . x}$

Bem, D. J., \& Funder, D. C. (1978). Predicting more of the people more of the time: Assessing the personality of situations. Psychological Review, 85, 485-500. doi: 10.1037/0033$\underline{295 X .85 .6 .485}$

Black, J. S., \& Ashford, S. J. (1995). Fitting in or making jobs fit: Factors affecting mode of adjustment for new hires. Human Relations, 48, 421-437. doi:10.1177/001872679504800407

Bolino, M.C., \&Turnley, W.H. (1999). Measuring impression management in organizations: A scale development based on Jones and Pittman Taxonomy.Organizational Research Methods, 2, 187-206. doi:10.1177/109442819922005

Brislin, R.W., (1980). Translation and content analysis of oral and written material. In H.C. Triandis \& J.W. Berry (Eds.), Handbook of Cross-Cultural Psychology, (pp. 389444).Boston: Allyn and Bacon.v.

Brockner, J., Grover, S., Reed, T.F., \& Dewitt, R.L. (1992). Layoffs, job insecurity and survivors work effort: Evidence of an inverted-U relationship. Academy of Management Journal, 35, 413-425. doi: $10.2307 / 256380$ 
Brockner, J., Spreitzer, G., Mishra, A., Hochwarter, W., Pepper, L., \& Weinberg, J. (2004).

Perceived control as an antidote to the negative effects of layoffs on survivors' organizational commitment and job performance. Administrative Science Quarterly, 49, 76100. doi: $10.2307 / 4131456$

Burgard, S.A., Brand, J.E., \& House, J.S. (2009). Perceived job insecurity and worker health in the United States. Social Science \& Medicine, 69, 777-785. doi:10.1016/j.socscimed.2009.06.029

Cardy, R.L., \& Dobbins, G.H. (1986). Affect and appraisal accuracy: Liking as an integral dimension in evaluation performance. Journal of Applied Psychology, 71, 672-678. doi:10.1037//0021-9010.71.4.672

Chan, D. (1998). The conceptualization and analysis of change over time: An integrative approach in corporating longitudinal means and covariance structures analysis (LMACS) and multiple indicator latent growth modeling (MLGM). Organizational Research Methods, 1,421-483. doi:10.1177/109442819814004

Chan, D. \& Schmitt, N. (2000).Interindividual differences in intraindividual changes in proactivity during organizational entry: A latent group modeling approach to understanding newcomer adaptation. Journal of Applied Psychology, 85, 190-210. doi: 10.1037/0021$\underline{9010.85 .2 .190}$

Cheng, G. H-L., \& Chan, D. K-S. (2008). Who suffers more from job insecurity? A metaanalytic review. Applied Psychology: An International Review, 57, 272-303. doi: 10.1111/j.1464$\underline{0597.2007 .00312 . \mathrm{x}}$

Crant, J. M. (2000). Proactive behavior in organizations. Journal of Management,26,435-462. doi: $10.1177 / 014920630002600304$ 
De Cuyper, N, \& De Witte, H. (2006). The impact of job insecurity and contract type on attitudes, well-being and behavioural reports: A psychological contract perspective. Journal of Occupational and Organizational Psychology, 79, 395-409.

\section{doi:10.1177/0959680107086113}

Delery, J. E., \&Kacmar, K. M. (1998).The influence of applicant and interviewer characteristics on the use of impression management. Journal of Applied Social Psychology, 28, 16491669. doi:10.1111/j.1559-1816.1998.tb01339.x

Eastman, K. K. (1994). In the eyes of the beholder: An attributional approach to ingratiation and organizational citizenship behavior. Academy of Management Journal, 37, 1379-1391. doi: $\underline{10.2307 / 256678}$

Ellis, A. P. J., West, B. J., Ryan, A. M., \&DeShon, R. P. (2002). The use of impression management tactics in structured interviews: A function of question type? Journal of Applied Psychology, 87, 1200-1208. doi:10.1037//0021-9010.87.6.1200

Festinger, L. (1957). A theory of cognitive dissonance. Stanford, CA: Stanford University Press.

Gilmore, D.C., \& Ferris, G.R. (1989).The effects of applicant impression management tactics on interviewer judgments. Journal of Management, 15, 557-564. doi:10.1177/014920638901500405.

Goldberg, L. R. (1992). The development of markers of the Big-Five factor structure. Psychological Assessment, 4, 26-42. doi: 10.1037/1040-3590.4.1.26

Grant, A. M., \& Ashford, S. J. (2008). The dynamics of proactivity at work. Research in. Organizational Behavior, 28, 3-34. doi:10.1016/j.riob.2008.04.002. 
Grant, A. M., \& Mayer, D. M. (2009). Good soldiers and good actors: Prosocial and impression management motives as interactive predictors of affiliative citizenship behaviors. Journal of Applied Psychology, 94, 900-912. doi: 10.1037/a0013770

Griffin, M. A., A. Neal \& S. K. Parker (2007). A new model of work role performance: positive behavior in uncertain and interdependent contexts. Academy of Management Journal, 50, 327-347. doi: 10.5465/AMJ.2007.24634438

Hellgren, J., \& Sverke, M. (2003). Does job insecurity lead to impaired well-being or vice versa? Estimation of cross-lagged effects using latent variable modeling. Journal of Organizational Behavior, 24, 215-236. doi: 10.1002/job.184

Hogg, M. A. (2000). Subjective uncertainty reduction through self-categorization: A motivational theory of social identity processes. European Review of Social Psychology, 11, 223-255. doi: 10.1080/14792772043000040

Hogg, M. A. (2007). Uncertainty-identity theory. In M. P. Zanna (Ed.), Advances in experimental social psychology (Vol. 39, pp. 69-126). San Diego, CA: Academic Press. doi:

\section{$\underline{10.1016 / \mathrm{S} 0065-2601(06) 39002-8}$}

Huang, G., Lee, C., Ashford, S., Chen, Z., \&Ren, X. (2010). Affective job insecurity: A mediator of the cognitive job insecurity and employee outcomes relationships. International Studies of Management and Organizations, 40, 20-39. doi:10.2753/IMO0020-8825400102

Huang, G., Niu, X., Ashford, S. J., \& Lee, C. (2012a). Differentiating cognitive and affective job insecurity: Antecedents and outcomes. Journal of Organizational Behavior, 33, 752-769. doi: $10.1002 /$ job.1815 
Huang, G., Zhao, H. H. \& Lee, C. (2012b). Job insecurity in China: A critical review. In X. Huang \& M. H. Bond (Eds.) The Handbook of Chinese Organizational Behavior: Integrating Theory, Research, and Practice, Cheltenham, UK: Edward Elgar Publishing.

Hui, C., Lam, S. S. K., \& Law, K. S. (2000). Instrumental values of organizational citizenship behavior for promotion: A field quasi-experiment. Journal of Applied Psychology, 85, 822828. doi: $10.1037 / 0021-9010.85 .5 .822$

Isen, A. M., Johnson, M. M. S., Mertz, E., \& Robinson, G. F. (1985).The influence of positive affect on the unusualness of word associations. Journal of Personality and Social Psychology, 48, 1413-1426. doi:10.1037//0022-3514.48.6.1413

Isen, A. M., Niedenthal, P., \& Cantor, N. (1992). An influence of positive affect on social categorization. Motivation and Emotion, 16, 65-78. doi:10.1007/BF00996487

Judge, T.A., \& Ferris, G.R. (1993). Social context of performance evaluation decisions. Academy of Management Journal, 36, 80-105. doi:10.2307/256513

Kipnis, D. \& Schmidt, S. (1988). Upward-influence styles: Relationship with performance evaluations, salary, and stress. Administrative Science Quarterly, 33, 528-542. doi:10.2307/2392642

Kishton, J. M., \& Widaman, K. F. (1994). Unidimensional versus domain representative parceling of questionnaire items: An empirical example. Educational and Psychological Measurement, 54, 757-765. doi: 10.1177/0013164494054003022

Klein, A. \&Moosbrugger (2000). Maximum likelihood estimation of latent interaction effects with the LMS method. Psychometrika, 65, 457-474. doi:10.1007/BF02296338

Kline, R.B. (2010). Principles and practice of structural equation modeling. New York: Guilford Press. 
Kraimer, M. L., Wayne, S. J., Liden, R. C., \& Sparrowe, R. T. (2005).The role of job security in understanding the relationship between employees’ perceptions of temporary workers and employees’ performance. Journal of Applied Psychology, 90, 389-398. doi:10.1037/0021$\underline{9010.90 .2 .389}$

Lam, W., Huang, X., \& Snape, E. (2007). Feedback-seeking behavior and leader-member exchange: Do supervisor-attributed motives matter? Academy of Management Journal, 50, 348-363. doi: 10.5465/AMJ.2007.24634440

Lance, C. E., Vandenberg, R. J. \& Self, R. M. (2000). Latent growth models of individual change: the case of newcomer adjustment. Organizational Behavior and Human Decision Making Processes, 83, 107-140. doi: 10.1006/obhd.2000.2904

Leary, M. R., \& Kowalski, R. M. (1990). Impression management: A literature review and twocomponent model. Psychological Bulletin, 107, 34-47. doi:10.1037//0033-2909.107.1.34

Lee, C., Bobko, P., \& Chen, Z. X. (2006). Investigation of the multidimensional model of job insecurity in China and the USA. Applied Psychology: an International Review, 55, 512540. doi:10.1111/j.1464-0597.2006.00233.x

Lefkowitz, J. (2000). The role of interpersonal affective regard in supervisory performance ratings: A literature review and proposed causal model. Journal of Occupational and Organizational Psychology, 73, 67-85.

Lindahl, L. G. (1949). What makes a good job? Personnel, 25, 263-266. Unique Identifier: 1950-00342-001

Little, T. D., Cunningham, W. A., Shahar, G., \& Widaman, K. F. (2002). To parcel or not to parcel: Exploring the question, weighing the merits. Structural Equation Modeling, 9, 151-173. doi: 10.1207/S15328007SEM0902_1 
Loza, J. (2009). 10 ways to keep your job despite the tough economy. Retrieved from http://www.techrepublic.com/blog/10things/10-ways-to-keep-your-job-despite-the-tough$\underline{\text { economy/701 }}$

McArdle, J.J. (2009). Latent variable modeling of differences in changes with longitudinal data. Annual Review of Psychology, 60, 577-605. doi:10.1146/annurev.psych.60.110707.163612

McArdle , J. J., \& Nesselroade, J. R. (1994). Structuring data to study development and change. In S. H. Cohen \& H. W. Reese (Eds.), Lifespan developmental psychology: Methodological innovations (pp.223-268). Hillsdale, NJ: Erlbaum.

McCrae, R. R., \& Costa, P. T. (1987). Validation of the five-factor model of personality across instruments and observers. Journal of Personality and Social Psychology, 52, 81-90. doi:10.1037/0022-3514.52.1.81

Morrison, E. W. (1994). Role definitions and organizational citizenship behavior: The importance of employee's perspective. Academy of Management Journal, 37, 1543-1567. doi: $10.2307 / 256798$

Muthén, B. \& Muthén, L. (2009). Mplus 6.0 User’s Guide. Los Angeles: Muthén and Muthén. Nicholson, N. (1984). A theory of work role transitions. Administrative Science Quarterly, 29, 172-191. doi: $10.2307 / 2393172$

Parker, S. K., Williams, H., \& Turner, N. (2006). Modeling the antecedents of proactive behavior at work. Journal of Applied Psychology, 91, 636-652. doi: 10.1037/0021-9010.91.3.636

Podsakoff, P.M. \& MacKenzie, S.B. (1989). A second generation measure of organizational citizenship behavior. Working paper, Indiana University. 
Probst, T. M. (2003). Development and validation of the job security index and the job security satisfaction scale: A classical test theory and IRT approach. Journal of Occupational and Organizational Psychology, 76(4), 451-467. doi:10.1348/096317903322591587

Rosenblatt, Z. and A. Ruvio (1996). A test of a multidimensional model of job insecurity: the case of Israeli teachers, Journal of Organizational Behavior, 17, 587-605. doi:10.1002/(SICI)1099-1379(199612)17:1+<587::AID-JOB825>3.3.CO;2-J

Rosenfeld, P. R., Giacalone, R. A., \& Riordan, C. A. (1995).Impression management in organizations: theory, measurement, and practice. New York: Routledge.

Roskies, E., Louis-Guerin, C., \& Fournier, C. (1993). Coping with job insecurity: How does personality make a difference? Journal of Organizational Behavior, 14, 617-630. doi:10.1002/job.4030140702

Schifferes, S. (2009). Job insecurity is increasing. Retrieved from http://news.bbc.co.uk/2/hi/business/7989670.stm.

Schlenker, B.R. (1980). Impression management: The self-concept, social identity and interpersonal relations. Monterey, CA: Brooks/Cole.

Selzer, S. (1950). Studying job satisfaction among hospital attendants. Public Personnel Review, 11, 26-29.

Simon, H. (1997). Administrative behavior, 4th Ed.New York: The Free Press.

Snyder, M. (1974). Self-monitoring of expressive behavior. Journal of Personality and Social Psychology, 30, 526-537. doi:10.1037/h0037039

Sverke, M., J. Hellgren, \& K. Näswall. (2002). No security: A meta-analysis and review of job insecurity and its consequences. Journal of Occupational Health Psychology, 7, 242-264. doi: 10.1037/1076-8998.7.3.242 
Turner, T. (2013). Keeping Your Job in a Tough Economy. Retrieved from http://voices.yahoo.com/keeping-job-tough-economy-11988083.html?cat=3

Vale, D. (2012). To keep their jobs, employees must make good impressions. Retrieved from http://www.examiner.com/article/to-keep-their-jobs-employees-must-make-goodimpressions

Vandenberg, R. J. (2002). Toward a further understanding of and improvement in measurement invariance methods and procedures. Organizational Research Methods, 5, 139-158. doi: $\underline{10.1177 / 1094428102005002001}$

Vandenberg, R. J., \& Lance, C. E. (2000). A review and synthesis of the measurement invariance literature: Suggestions, practices, and recommendations for organizational research. Organizational Research Methods, 2, 4-69. doi:10.1177/109442810031002

Wayne, S.J., \& Ferris, G.R. (1990). Influence tactics, affect, and exchange quality in supervisorsubordinate interactions: A laboratory experiment and a field study. Journal of Applied Psychology, 75, 487-499. doi:10.1037//0021-9010.75.5.487

Wayne, S.J., \& Kacmar, K.M. (1991). The effects of impression management on the performance appraisal process. Organizational Behavior and Human Decision Processes, 48, 70-88. doi:10.1016/0749-5978(91)90006-F

Wayne, S.J., \&Liden, R.C. (1995). Effects of impression management on performance ratings: a longitudinal study. Academy of Management Journal, 38, 232-260. doi:10.2307/256734

Wong, Y. T., Wong, C. S., Ngo, H. Y., \& Lui, H. K. (2005). Different responses to job insecurity of Chinese workers in joint ventures and state-owned enterprises. Human Relations, 58, 1391-1418. doi:10.1177/0018726705060243 
Xin, K.R. (1997). Asian American managers: an impression gap? An investigation of impression management and supervisor-subordinate relationships. Journal of Applied Behavioral Science, 33, 335-355. doi:10.1177/0021886304263853

Xin, K.R., \&Tsui, A.S. (1996). Different strokes for different folks? Influence tactics by Asian American and Caucasian American managers. Leadership Quarterly, 7, 113-136. doi:10.1016/S1048-9843(96)90037-5 


\section{Table 1}

Descriptive Statistics and Correlations of Variables

\begin{tabular}{rlllllllll}
\hline & Variables & 1 & 2 & 3 & 4 & 5 & 6 & 7 & 8 \\
\hline 1 & Company & -- & & & & & & & \\
2 & Gender & $-.32^{* *}$ & -- & & & & & & \\
3 & Age & $.22^{* *}$ & $-.13^{*}$ & -- & & & & & \\
4 & Education & $-.17^{* *}$ & $.17^{* *}$ & $-.20^{* *}$ & -- & & & & \\
5 & Tenure & $.53^{* *}$ & $-.24^{* *}$ & $.65^{* *}$ & $-.18^{* *}$ & -- & & & \\
6 & Employee Type & $-.52^{* *}$ & .09 & $-.48^{* *}$ & -.07 & $-.62^{* *}$ & -- & & \\
7 & Trt. Insecurity & $.26^{* *}$ & $-.13^{*}$ & $.13^{*}$ & -.09 & $.26^{* *}$ & $-.15^{*}$ & $(.73)$ & \\
8 & Org. Change & $.18^{* *}$ & $-.18^{* *}$ & $.17^{* *}$ & -.04 & $.20^{* *}$ & $-.12^{*}$ & $.18^{* *}$ & $(.78)$ \\
9 & JI Time1 & .03 & $-.14^{*}$ & $.13^{*}$ & -.05 & $.14^{*}$ & -.01 & $.21^{* *}$ & $.16^{* *}$ \\
10 & JI Time3 & $.20^{* *}$ & $-.18^{* *}$ & .02 & -.11 & .08 & -.00 & $.16^{*}$ & .04 \\
11 & Sup. Liking & $-.14^{*}$ & -.03 & $-.16^{* *}$ & .03 & -.11 & $.16^{* *}$ & -.05 & -.04 \\
12 & Att. Motives & .03 & $-.14^{*}$ & .04 & .08 & .07 & -.04 & -.04 & -.03 \\
13 & IM Tactics & .10 & .04 & .01 & $-.14^{*}$ & .04 & -.03 & .05 & .03 \\
14 & PR Time2 & -.09 & .02 & -.03 & -.02 & -.04 & .09 & -.11 & .06 \\
15 & PR Time3 & -.04 & .03 & -.06 & .12 & -.06 & .00 & -.09 & -.05 \\
\hline & $M$ & 1.52 & 1.26 & 3.50 & 2.08 & 4.95 & 1.71 & 3.62 & 3.28 \\
& SD & 0.50 & 0.44 & 2.04 & 0.86 & 1.75 & 0.69 & 1.22 & 0.53 \\
\hline
\end{tabular}

Note. $\mathrm{N}=271 .{ }^{* *} p<.01 ;{ }^{*} p<.05 ; \mathrm{JI}=$ Job Insecurity; PR = Performance Rating; IM = Impression Management; Sup. Liking = supervisor Liking; Att. Motive = Attributed Motive; Org. change $=$ Organizational Change; Trt. Insecurity = Trait Insecurity Coefficients in the brackets are Cronbach's alpha values. 
Table 1 (Cont.)

Descriptive Statistics and Correlations of Variables

\begin{tabular}{|c|c|c|c|c|c|c|c|c|}
\hline & Variables & 9 & 10 & 11 & 12 & 13 & 14 & 15 \\
\hline 1 & Company & & & & & & & \\
\hline 2 & Gender & & & & & & & \\
\hline 3 & Age & & & & & & & \\
\hline 4 & Education & & & & & & & \\
\hline 5 & Tenure & & & & & & & \\
\hline 6 & Employee Type & & & & & & & \\
\hline 7 & Trt. Insecurity & & & & & & & \\
\hline 8 & Org. Change & & & & & & & \\
\hline 9 & JI Time1 & $(.82)$ & & & & & & \\
\hline 10 & JI Time3 & $.33 * *$ & $(.88)$ & & & & & \\
\hline 11 & Sup. Liking & -.04 & -.09 & $(.90)$ & & & & \\
\hline 12 & Att. Motives & .01 & .11 & -.04 & $(.76)$ & & & \\
\hline 13 & IM Tactics & $.18 * *$ & $.19 * *$ & $-.12 *$ & .01 & $(.94)$ & & \\
\hline 14 & PR Time2 & -.12 & -.09 & $.40 * *$ & .01 & $-.15^{*}$ & $(.77)$ & \\
\hline \multirow[t]{3}{*}{15} & PR Time3 & -.08 & -.10 & $.19 * *$ & -.09 & $-.12 *$ & $.17 * *$ & $(.72)$ \\
\hline & $M$ & 2.85 & 2.70 & 3.96 & 3.19 & 2.72 & 3.86 & 3.99 \\
\hline & $S D$ & 0.73 & 0.82 & 0.73 & 0.72 & 0.66 & 0.57 & 0.57 \\
\hline
\end{tabular}




\section{Table 2}

Unstandardized Estimates for Structural Model and Latent Change Score Model

\begin{tabular}{|c|c|c|}
\hline \multicolumn{3}{|l|}{ Means and standard deviations } \\
\hline JI Latent Change, mean & \multicolumn{2}{|l|}{$-.21 * *$} \\
\hline JI Latent Change, standard deviation & \multicolumn{2}{|l|}{.21} \\
\hline PR Latent Change, mean & \multicolumn{2}{|l|}{$.24 * *$} \\
\hline PR Latent Change, standard deviation & \multicolumn{2}{|l|}{.23} \\
\hline \multicolumn{3}{|l|}{ Covariances } \\
\hline JI Latent Change $\leftrightarrow$ PR Latent Change & \multicolumn{2}{|l|}{-.03} \\
\hline JI Latent Change $\leftrightarrow$ JI Time1 & \multicolumn{2}{|l|}{-.10} \\
\hline PR Latent Change $\leftrightarrow$ PR Time2 & \multicolumn{2}{|l|}{-.17} \\
\hline \multicolumn{3}{|l|}{ Residual variances } \\
\hline IM Tactics & \multicolumn{2}{|l|}{$.29 * *$} \\
\hline JI Latent Change & \multicolumn{2}{|l|}{$.50 * *$} \\
\hline PR Latent Change & \multicolumn{2}{|l|}{$.29 * *$} \\
\hline \multicolumn{3}{|l|}{ Regression weights } \\
\hline & \multicolumn{2}{|c|}{ Criterion variables } \\
\hline Predictors & \multicolumn{2}{|c|}{ IM Tactics } \\
\hline \multirow[t]{2}{*}{ JI Time1 } & \multicolumn{2}{|l|}{$.19 * *$} \\
\hline & JI Latent Change & PR Latent Change \\
\hline Company & $.30 * *$ & .07 \\
\hline Sex & -.05 & .05 \\
\hline Age & -.02 & .01 \\
\hline Education & -.03 & -.01 \\
\hline Tenure & -.00 & -.03 \\
\hline Employment Type & .06 & .02 \\
\hline Trt. Insecurity & .01 & .08 \\
\hline Org. Change & -.15 & -.18 \\
\hline JI Time1 & -- & .08 \\
\hline Sup. Liking & .04 & .06 \\
\hline Att. Motives & -.04 & $.44 * *$ \\
\hline IM Tactics & .18 & -.10 \\
\hline IM Tactics $\times$ Sup. Liking & $.30 * *$ & .04 \\
\hline IM Tactics $\times$ Att. Motives & -.10 & $.26^{*}$ \\
\hline
\end{tabular}

Note. $\mathrm{N}=271$. $\mathrm{JI}=$ job insecurity; $\mathrm{PR}=$ performance rating; $\mathrm{IM}=$ impression management; Sup. Liking = supervisor liking; Att. motive = attributed motive; Org. change $=$ perceived organizational change.

${ }^{* *} p<.01, * p<.05$ 
Reducing Job Insecurity 33

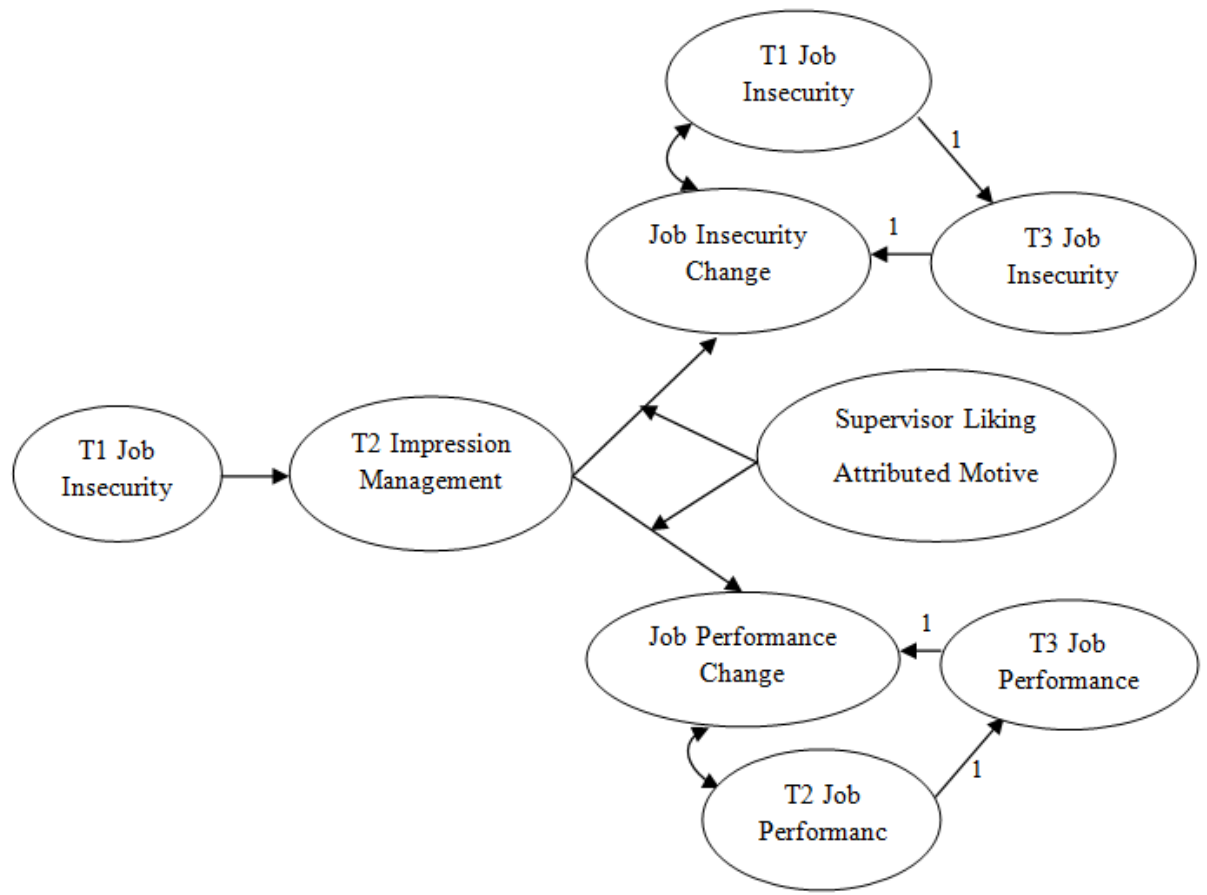

Figure 1. Proposed model. 


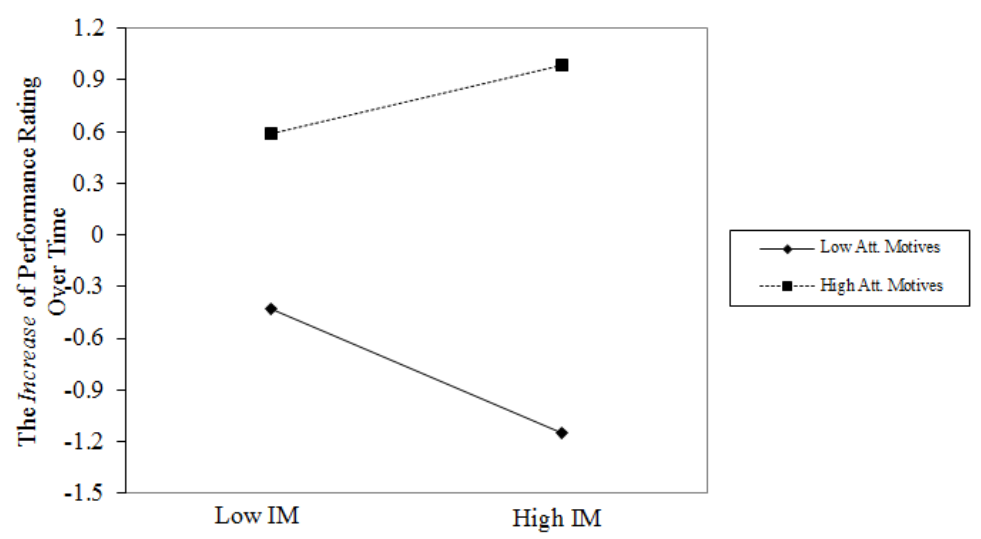

Note. Zero on the vertical axis represents the mean level of change (the outcome variables are latent change scores whose mean were scaled to zero in the data analysis).

Figure 2. Moderating effect of attributed altruistic motive (Att. Motive) on the relationship between impression management (IM) and the latent change score of performance rating.

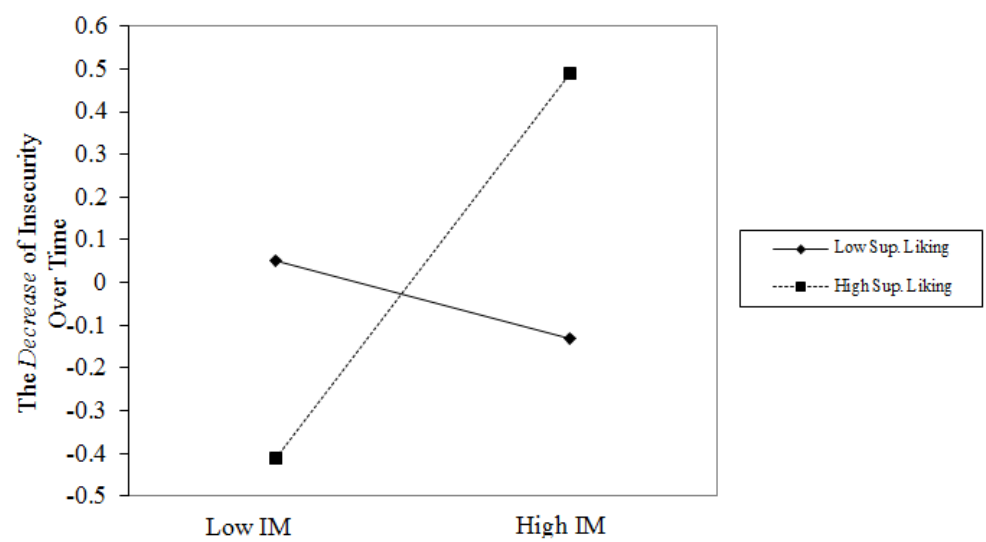

Note. Zero on the vertical axis represents the mean level of change (the outcome variables are latent change scores whose mean were scaled to zero in the data analysis).

Figure 3. Moderating effect of supervisor liking (Sup. Liking) on the relationship between impression management (IM) and the latent change score of job insecurity (JI). 


\section{Appendix}

\section{Results Using the Three Dimensions of Impression Management}

The scale we used for impression management has three dimensions, job-focused, supervisor-focused and self-focused. We did not test our hypotheses at dimensional level because our theoretical model is proposed at overall construct level. However, analysis at the dimensional level may give us more information regarding the different tactics. We therefore reported and discussed the results in this Appendix.

As shown in Table A1, results are in general consistent with the results of overall construct level analysis. However, there are some differences in effect sizes and significance levels among the three dimensions. In predicting job insecurity change, supervisor liking moderated selffocused but not job-focused and supervisor-focused impression management tactics. In predicting job performance rating change, supervisor attributed motive moderated the effect of job-focused and supervisor-focused but not self-focused impression management tactics. This result implies that self-focused tactics are less influential in affecting supervisors' judgments about the employees' performances but more influential in affecting affective experience of the self. We plotted the interactions in Figure A1 below. Interaction patterns and slope analysis at dimensional level are similar with those at overall level in general except that the effect of jobfocused tactics on performance rating increase is significant in the high altruistic attribution condition $(\beta=.24, p<.05)$. Such results showed that job-focused tactics are useful in enhancing performance rating when supervisors make altruistic attribution about employees’ motives.

[Insert Table A1 and Figure A1 about here.]

These results should, however, be taken with caution. The impression management measure we used (Wayne \& Ferris, 1990) has been widely adopted in prior literature at the 
overall level; the dimensions of the scale were based on exploratory factor analysis results rather than theoretical reasons. Bolino and Turnley (1999) questioned this dimensionality (using foci of the tactics to define the dimensions) and noted that it "makes deriving theoretically-based predictions about the causes and consequences of these different tactics somewhat difficult” (P.118). Indeed we found high correlations among the three dimensions ( $\rho=.56$ to $.62, p<.01$ ). For this reason, we formed our hypotheses and performed all the tests at the overall level in this study. 


\section{Table A1}

Unstandardized Estimates of the Predictors' Effects on the Latent Change Scores of Job Insecurity and Performance Rating at the Dimensional Level of Impression Management

\begin{tabular}{lll}
\hline & \multicolumn{2}{c}{ Criterion Variables } \\
Predictor Variables & JI Latent Change & PR Latent Change \\
\hline$\omega:$ Job-foc $\times$ Sup. Liking & .19 & .03 \\
$\omega:$ Sup-foc $\times$ Sup. Liking & .12 & .01 \\
$\omega:$ Self-foc $\times$ Sup. Liking & $.45^{* *}$ & -.03 \\
$\omega:$ Job-foc $\times$ Att. Motive & .03 & $.63^{* *}$ \\
$\omega:$ Sup-foc $\times$ Att. Motive & -.15 & $.31^{*}$ \\
$\omega:$ Self-foc $\times$ Att. Motive & .10 & .11 \\
\hline
\end{tabular}

Note. $\mathrm{N}=271 . \mathrm{JI}=$ job insecurity; PR = performance rating; Job-foc = Jobfocused Tactics; Sup-foc $=$ Supervisor-focused Tactics; Self-foc $=$ Selffocused Tactics; Sup. Liking = Supervisor Liking; Att. Motive = Attributed Motive

** $p<.01, * p<.05$ 
Reducing Job Insecurity 38
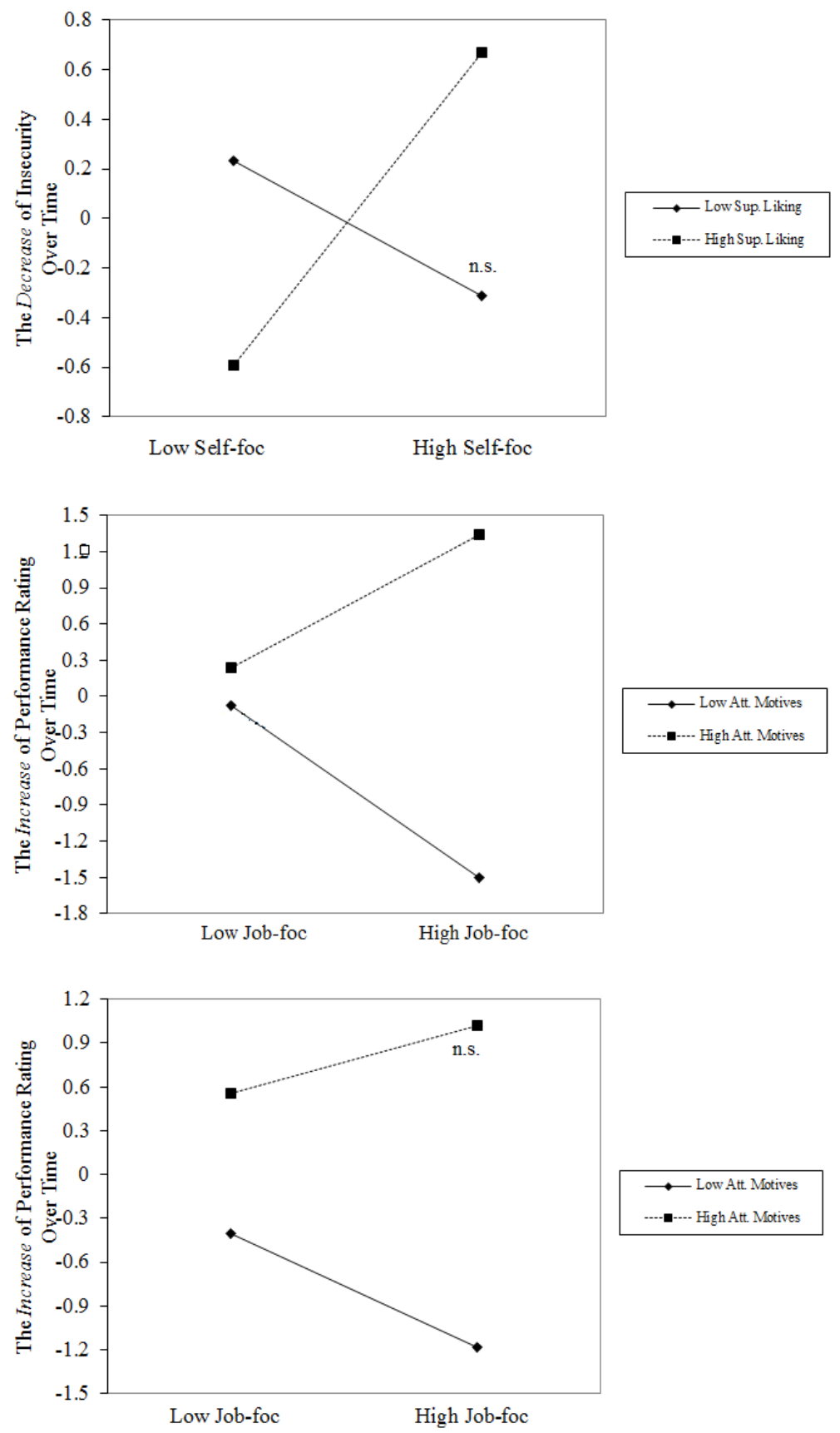

Figure A1. Interaction Plots at Dimensional Levels of Impression Management. 